\title{
Modeling rainfall as a constraining factor for Cocoa yield in Ondo State
}

\author{
Ajayi I. R. ${ }^{1}$, Afolabi M.O. ${ }^{1}$, Ogunbodede E.F. ${ }^{2}$ and Sunday A.G. ${ }^{1}$ \\ ${ }^{1}$ Department of Physics and Electronics, Adekunle Ajasin University, Akungba-Akoko, Ondo \\ State, Nigeria. \\ ${ }^{2}$ Department of Geography and Planning Science, Adekunle Ajasin University, Akungba- \\ Akoko, Ondo State, Nigeria.
}

\begin{abstract}
Rainfall is undoubtedly a determining agro-meteorological factor in the cultivation and production of cocoa. This work has revealed that rainfall has a constraining ability on cocoa yield in the core cocoa production areas of Ondo state, Nigeria. It was also established that cocoa production is in its best in areas like: Idanre, Ondo, Akure, Ile-Oluji, Owo e.t.c, which have yields above 1000MT per annum and rainfall lesser than $51.30 \mathrm{~mm}$. Cocoa yield was also shown to be the inverse of annual rainfall level. This was evident as cocoa yield increased in the early and latter months of the year when the rains are yet to fully come, and suffered in the mid year at the heart of raining season. A model of rainfall as it affected cocoa yields was achieved in this work.
\end{abstract}

Keywords: Yield, cocoa producing areas, sustain, location, constraining.

\section{INTRODUCTION}

Cocoa is generally conceived by most people to mean a brownish powder used in the production of chocolate and is also sometimes interchanged for cocoa tree. The cocoa tree, though native to the Americas, may have had a larger range of cultivation in the past. Cacao (or Cocoa) trees grow in a limited geographical zone, of approximately 20 degrees to the north and south of the Equator. Nearly $70 \%$ of the world crop is grown in West Africa (Cocoa Bean, http://www.ehow.com/cocoa-beans/).

Nigeria was ranked 4th in the world production of cocoa in 2004. Nigeria was able to produce 0.37 million metric tons of cocoa, which amounted to $10.28 \%$ of the world cocoa production that year. See table 1.1. The world cocoa production is on the scale of 3 million tons every year.

Table 1.1: World Cocoa Production in 2004

\begin{tabular}{|c|c|}
\hline Country & Production (million metric tons) \\
\hline Cote d'Ivoire & 1.33 \\
\hline Ghana & 0.74 \\
\hline Indonesia & 0.45 \\
\hline Nigeria & 0.37 \\
\hline Brazil & 0.17 \\
\hline Cambodia & 0.13 \\
\hline Ecuador & 0.09 \\
\hline
\end{tabular}

Source: UN Food \& Agriculture Organisation (FAO)

As Cocoa farmers in many countries lack information on production and marketing practices to help them improve their livelihoods, Nigerian farmers are not in any way exempted. Efforts are made to sustain cocoa production in the cocoa growing regions through public-private partnerships such as International Institute of Tropical Agriculture's (IITA) Sustainable Tree Crops Program (STCP). The World Cocoa Foundation (WCF) has reached over 300,000 small scale cocoa farmers together with their families in its regional programmes in West Africa, Latin America and Southeast Asia. Graduates of WCFsupported farmer field schools report income improvements of 22-55 percent or more, through improved cultivation and marketing practices.

In the Nigerian scenario, research sponsored by the National Space Research and Development Agency (NASRDA) on Sustainable Optimum Cocoa Production in Ondo State, the chief cocoa producing state in the country, is on-going. The NASRDA support for cocoa research is not only intended to provide the needed information on good production practices, but also aims at discovering modern techniques that will optimize cocoa production. It is also to further determine the combination of weather parameters (collected in situ) that can produce optimal yield of cocoa from various sampling locations.

Cocoa (Theobroma cacao L.) remains a major export in Nigeria. In its report in 1998 the Central Bank of Nigeria that "a revenue of 7459.3 million Naira (US\$ 53,280 at 140 per US\$) was derived from dried cocoa 
beans (half of the income attributed to the total export of major agricultural products)". "Cocoa was first cultivated in the western region of Nigeria in 1890" (Adegeye, 1996). Its cultivation gained prominence rapidly in Nigeria such that by 1965 , Nigeria became the second largest producer in the world (Adegeye, 1996). The cocoa producing states lie within the rainforest zone of Nigeria which includes Ondo, Ogun, Oyo, Ekiti, Edo, Delta, Cross-Rivers and Akwa-lbom; with over $50 \%$ of the total quantity of cocoa produced for export or utilized locally per annum comes from Ondo State (Adegeye, 1996). The production, however, has declined in recent years; a fact attributed partly to poor soil quality (Ajobo, 1980; Egbe, 1989).

Crop production involves a complex interaction between the environment, soil parameters, and nutrient dynamics (Ukpong and Moses, 2001). Failure to understand these complexities has resulted in lack of good crop production and management techniques; hence agricultural production has tended to be low. "It is well known that cocoa production is highly sensitive to changes in climate, from length and intensity of sunshine, to rainfall and water application, soil condition and temperature due to evapotranspiration effects." (Anim-Kwapong, et al, 2008) In other words, agro-meteorological elements-Temperature, Rainfall, Humidity, Vegetation, soil organic matter content, Porosity and Permeability could greatly 'or partly' act as constraining factors for cocoa production hence, the need for a thorough study to be carried out on these environment-dependent factors.

In this research work attempt was made to determine the effects which rainfall-an agro-meteorological element has on the cocoa producing areas of Ondo state, Nigeria in relation to the cocoa yield from the sampled farmlands in the areas.

Sampling, Materials and Methods: A total of 17 sampling locations-cocoa farmlands, which are located within the cocoa producing local governments of Ondo State were visited. Data were collected from each of these sampling locations, and a uniform sampling method was used in all. At each sampling location, the GPS reading of three randomly-chosen points around the farmland were taken and recorded. A soil point was strategically chosen within the farm where GPS reading, Elevation, and Soil temperature were taken and recorded. The soil type and vegetation were also mechanically determined and recorded for each of the farmlands visited. See table 1.2 .

Garmin's manufactured hand-held Global Positioning System GPS (Model - GPS76) receiver with a built-in Quad Helix antenna, and Wide Area Augmentation System (WAAS) capable, of a good accuracy was used for collection of co-ordinate data i.e. Longitude and Latitude in the farmlands. At every sampling point, the GPS receiver after it was powered on, initializes and starts acquiring satellites. The GPS receiver remains in this mode until it has acquired at least three satellite signals. But after acquiring at least four satellite signals, the receiver enters into the 3D GPS Location where the information is provided by the GPS on current position and altitude in the farmland. The sampling location was therefore recorded at this stage. This aided in GIS cocoa farmland map classification.

The rainfall classification was carried out using the Inverse Distance weighted (IDW) interpolation method. Surface interpolation is any formal technique that uses values at sampled locations to predict values at un-sampled locations. Inverse Distance Weighted (IDW) interpolation implements a basic law of geography-things that are close to one another are more alike than things that are far apart. To predict a value for any unmeasured location, IDW uses the measured values surrounding the prediction location. Those measured values closest to the prediction location have more influence on the predicted value than those that are farther away, hence the name 'inverse distance weighted'. IDW assumes that each measured point has some local influence that diminishes with distance. This method was used for interpolation in the analysis.

\section{RESULTS}

The results as collected from the sampled farmlands is as shown in table1.2, it shows the location of each farmlands visited, elevation and the soil type and vegetation observed in these areas. Due to absence of a meteorological station on the farmlands, the relevant local government rainfall and yield data (tables $1.3 \mathrm{a}-\mathrm{c} \& 1.4 \mathrm{a}-\mathrm{b}$ ) were collected at the Ministry of Agriculture, Akure in Ondo state, Nigeria. 
Am. J. Sci. Ind. Res., 2010, 1(2): 127-134

Table 1.2: Meteorological factors as recorded from the sampled cocoa farmlands

\begin{tabular}{|c|c|c|c|c|c|c|c|}
\hline $\mathrm{S} / \mathrm{N}$ & $\begin{array}{l}\text { Sampling } \\
\text { Locations }\end{array}$ & $\begin{array}{l}\text { Sampling } \\
\text { Crop }\end{array}$ & Soil Type & Latitude & Longitude & Vegetation & Elevation(m) \\
\hline 1 & Ikpemen & Cocoa & Highly Laterized soil & $7^{\circ} 15^{\prime} 04.90 "$ & $5^{\circ} 35^{\prime} 57.8^{\prime \prime}$ & Tropical rain forest & 287.5 \\
\hline 2 & Ago-panu & Cocoa & Sandy soil & $7^{\circ} 17^{\prime} 19.60^{\prime \prime}$ & $5^{\circ} 36^{\prime} 59.6^{\prime \prime}$ & Savannah & 260.3 \\
\hline 3 & Okeluse & Cocoa & Sandy soil & $6^{\circ} 47^{\prime} 49.00^{\prime \prime}$ & $5^{\circ} 35^{\prime} 16.6^{\prime \prime}$ & Tropical rain forest & 110.2 \\
\hline 4 & Ute & Cocoa & Dark loamy & $6^{\circ} 52^{\prime} 12.90^{\prime \prime}$ & $5^{\circ} 36^{\prime} 20.7^{\prime \prime}$ & Tropical Rain forest & 101.3 \\
\hline 5 & Arimogija & Cocoa & Dark loamy & $6^{\circ} 49^{\prime} 19.30^{\prime \prime}$ & $5^{\circ} 41^{\prime} 40.2^{\prime \prime}$ & Tropical Rain forest & 78.4 \\
\hline 6 & Ipele & Cocoa & Highly Laterized soil & $7^{\circ} 03^{\prime} 14.80^{\prime \prime}$ & $5^{\circ} 40^{\prime} 53.5^{\prime \prime}$ & Savannah & 178.5 \\
\hline 7 & Igbara-oke & Cocoa & Sandy soil & $7^{\circ} 22^{\prime} 47.30^{\prime \prime}$ & $5^{\circ} 03^{\prime} 1.90^{\prime \prime}$ & Tropical rain forest & 343.3 \\
\hline 8 & Ilara-mokin & Cocoa & Sandy soil & $7^{\circ} 20^{\prime} 41.50^{\prime \prime}$ & $5^{\circ} 06^{\prime} 7.00^{\prime \prime}$ & Tropical rain forest & 340 \\
\hline 9 & Ibule-soro & Cocoa & Sandy soil & $7^{\circ} 19^{\prime} 04.10^{\prime \prime}$ & $5^{\circ} 06^{\prime} 49.4^{\prime \prime}$ & Tropical rain forest & 383.9 \\
\hline 10 & Uso & Cocoa & Sandy soil & $7^{\circ} 15^{\prime} 28.50^{\prime \prime}$ & $5^{\circ} 25^{\prime} 9.10^{\prime \prime}$ & Tropical rain forest & 326.6 \\
\hline 11 & Ogbese & Cocoa & Sandy soil & $7^{\circ} 14^{\prime} 03.00^{\prime \prime}$ & $5^{\circ} 22^{\prime} 57.7^{\prime \prime}$ & Tropical rain forest & 304.5 \\
\hline 12 & Oba-Akoko & Cocoa & Highly Laterized soil & $7^{\circ} 22^{\prime} 02.20^{\prime \prime}$ & $5^{\circ} 43^{\prime} 21.3^{\prime \prime}$ & Tropical rain forest & 304.7 \\
\hline 13 & Ondo & Cocoa & Sandy soil & $6^{\circ} 58^{\prime} 25.20^{\prime \prime}$ & $4^{\circ} 50^{\prime} 54.1^{\prime \prime}$ & Tropical rain forest & 227.2 \\
\hline 14 & Ile-oluji & Cocoa & Sandy/Laterized & $7^{\circ} 09^{\prime} 45.70^{\prime \prime}$ & $4^{\circ} 51^{\prime} 44.2^{\prime \prime}$ & Tropical rain forest & 253.3 \\
\hline 15 & Idanre & Cocoa & Sandy soil & $7^{\circ} 10^{\prime} 38.60 "$ & $5^{\circ} 09^{\prime} 00.1^{\prime \prime}$ & Tropical rain forest & 297.6 \\
\hline 16 & Oda-Akure & Cocoa & Sandy/Laterized & $7^{\circ} 09^{\prime} 48.80^{\prime \prime}$ & $5^{\circ} 14^{\prime} 53^{\prime \prime}$ & Tropical rain forest & 324.6 \\
\hline 17 & Ifon & Cocoa & Sandy soil & $6^{\circ} 55^{\prime} 00.70^{\prime \prime}$ & $5^{\circ} 45^{\prime} 4.70^{\prime \prime}$ & Tropical rain forest & 185.8 \\
\hline
\end{tabular}

Table 1.3 (a): Ondo State Ministry of Agriculture data on cocoa production in year 2005

\begin{tabular}{|l|l|l|l|}
\hline S/N & COCOA PRODUCING AREAS & YIELD (MT) & RATING \\
\hline 1 & AKURE NORTH & $1,536.5$ & 10 th \\
\hline 2 & AKURE SOUTH & $7,862.5$ & $3 \mathrm{rd}$ \\
\hline 3 & IDANRE & $14,334.5$ & $1 \mathrm{st}$ \\
\hline 4 & ORE & $5,053.5$ & 4 th \\
\hline 5 & ONDO EAST & $3,604.5$ & 7 th \\
\hline 6 & ONDO WEST & $8,986.5$ & $2 \mathrm{nd}$ \\
\hline 7 & ALADE(IDANRE) & $2,350.5$ & 8 th \\
\hline 8 & ILE-OLUJI & 3,682 & 6 th \\
\hline 9 & AKOKO NORTH EAST & 647 & 14 th \\
\hline 10 & AKOKO NORTH WEST & 5 & 17 th \\
\hline 11 & AKOKO SOUTH EAST & NA & - \\
\hline 12 & AKOKO SOUTH WEST & 650 & 13 th \\
\hline 13 & ILARA & 1,669 & 9 th \\
\hline 14 & OWO & 4,056 & 5 th \\
\hline 15 & OSE(IFON) & 1,535 & 11 th \\
\hline 16 & OKITIPUPA & 3 & 18 th \\
\hline 17 & IRELE & $2,75.5$ & 15 th \\
\hline 18 & ONIPARAGA (ODIGBO) & 802.5 & 12 th \\
\hline 19 & WAREHOUSE & 23 & 16 th \\
\hline & TOTAL & 57076 & \\
\hline
\end{tabular}


Table 1.3 (b): Ondo State Ministry of Agriculture data on cocoa production in year 2006

\begin{tabular}{|c|c|c|c|}
\hline S/N & COCOA PRODUCING AREAS & YIELD (MT) & RATING \\
\hline 1 & AKURE NORTH & 2277.5 & 9th \\
\hline 2 & AKURE SOUTH & 5116 & $3 r d$ \\
\hline 3 & IDANRE & 17015 & $1 \mathrm{st}$ \\
\hline 4 & ORE & 3745.5 & 6th \\
\hline 5 & ONDO EAST & 2564 & 8th \\
\hline 6 & ONDO WEST & 12287 & 2nd \\
\hline 7 & ALADE(IDANRE) & 3134 & 7th \\
\hline 8 & ILE-OLUJI & 4211 & 5th \\
\hline 9 & AKOKO NORTH EAST & 678.5 & 13th \\
\hline 10 & AKOKO NORTH WEST & NA & - \\
\hline 11 & AKOKO SOUTH EAST & 34 & 16th \\
\hline 12 & AKOKO SOUTH WEST & 542 & 14th \\
\hline 13 & ILARA & 1622 & 10th \\
\hline 14 & OWO & 5083 & 4th \\
\hline 15 & OSE(IFON) & 1150 & 11th \\
\hline 16 & OKITIPUPA & NA & - \\
\hline 17 & IRELE & 112.5 & 15th \\
\hline 18 & ONIPARAGA (ODIGBO) & 709.5 & 12th \\
\hline 19 & WAREHOUSE & NA & - \\
\hline 20 & AJEBAMIDELE & NA & - \\
\hline \multirow[t]{2}{*}{21} & HEADQUARTERS & NA & - \\
\hline & TOTAL & 61835.5 & \\
\hline
\end{tabular}

Table 1.3(c): Ondo State Ministry of Agriculture data on cocoa production in year 2007

\begin{tabular}{|l|l|l|l|}
\hline $\mathbf{S} / \mathbf{N}$ & COCOA PRODUCING AREAS & YIELD (MT) & RATING \\
\hline 1 & AKURE & $3,706.50$ & 6 th \\
\hline 2 & IDANRE & 11306 & $1 \mathrm{st}$ \\
\hline 3 & ORE & 4486 & $3 \mathrm{rd}$ \\
\hline 4 & ONDO EAST & 2739 & 8 th \\
\hline 5 & ONDO WEST & 8563.5 & $2 \mathrm{nd}$ \\
\hline 6 & ALADE & 2885.5 & 7 th \\
\hline 7 & ILE-OLUJI & 4 th \\
\hline 8 & AKOKO NORTH EAST & 4152 & 11 th \\
\hline 9 & AKOKO NORTH WEST & 399 & - \\
\hline 10 & AKOKO SOUTH EAST & NA & 14 th \\
\hline 11 & AKOKO SOUTH WEST & 206 & 13 th \\
\hline 12 & ILARA & 342 & 10 th \\
\hline 13 & OWO & 799 & 5 th \\
\hline 14 & OSE & 3745.5 & 9 th \\
\hline 15 & OKITIPUPA & 1053.5 & - \\
\hline 16 & IRELE & NA & 15 th \\
\hline 17 & ONIPARAGA & 199 & 12 th \\
\hline & TOTAL & 392 & 45004.5 \\
\hline
\end{tabular}


Am. J. Sci. Ind. Res., 2010, 1(2): 127-134

Table 1.4 (a): Monthly distribution of Rainfall and cocoa Yield $2005-2007$

\begin{tabular}{|l|l|l|l|l|l|l|}
\hline & \multicolumn{2}{c}{ 2005 } & \multicolumn{2}{c|}{ 2006 } & \multicolumn{2}{c|}{ 2007 } \\
\hline & Rainfall (mm) & Yield (MT) & Rainfall (mm) & Yield (MT) & Rainfall (mm) & Yield (MT) \\
\hline January & NA & $10,040.00$ & 13.58 & $7,210.00$ & 4.40 & $6,303.00$ \\
\hline February & 16.19 & $4,685.50$ & 20.21 & $4,075.00$ & 21.40 & 980.50 \\
\hline March & 73.84 & $2,973.50$ & 60.06 & $2,103.50$ & 35.10 & 243.00 \\
\hline April & 197.98 & $1,206.50$ & 72.21 & $3,742.00$ & 96.50 & 410.00 \\
\hline May & 117.77 & $1,397.50$ & 109.14 & $4,254.00$ & 150.70 & $1,508.00$ \\
\hline June & 167.73 & $1,796.50$ & 100.32 & $3,745.00$ & 188.60 & 826.00 \\
\hline July & 183.08 & $1,184.50$ & 166.35 & $3,035.50$ & 201.40 & 960.50 \\
\hline August & 24.79 & $1,873.00$ & 164.79 & $3,243.50$ & 146.70 & $2,706.00$ \\
\hline September & 115.19 & $3,196.50$ & 284.46 & $3,328.50$ & 183.30 & $2,822.50$ \\
\hline October & 89.13 & $5,179.00$ & 135.43 & $4,757.00$ & 129.70 & $4,377.50$ \\
\hline November & 8.10 & $13,516.50$ & 15.96 & $12,066.00$ & 54.00 & $9,647.00$ \\
\hline December & 13.44 & $10,027.50$ & NA & $10,275.50$ & 20.80 & $14,220.50$ \\
\hline TOTAL & & $\mathbf{5 7 , 0 7 6 . 5 0}$ & & $\mathbf{6 1 , 8 3 5 . 5 0}$ & & $\mathbf{4 5 , 0 0 4 . 5 0}$ \\
\hline
\end{tabular}

Source: Ministry of Agriculture, Ondo state, Nigeria.

Table 1.4 (b): Rainfall and cocoa Yield Summary

\begin{tabular}{|l|c|c|c|}
\cline { 2 - 4 } \multicolumn{1}{c|}{} & $\mathbf{2 0 0 5}$ & $\mathbf{2 0 0 6}$ & $\mathbf{2 0 0 7}$ \\
\hline $\begin{array}{l}\text { Rainfall } \\
(\mathrm{mm})\end{array}$ & $1,007.24$ & $1,142.51$ & $1,232.60$ \\
\hline Yield (MT) & $57,076.50$ & $61,835.50$ & $45,004.50$ \\
\hline
\end{tabular}

\section{DISCUSSION OF RESULTS}

The study area is essentially the cocoa production areas of Ondo state as indicated in the map below (figure 1.0).

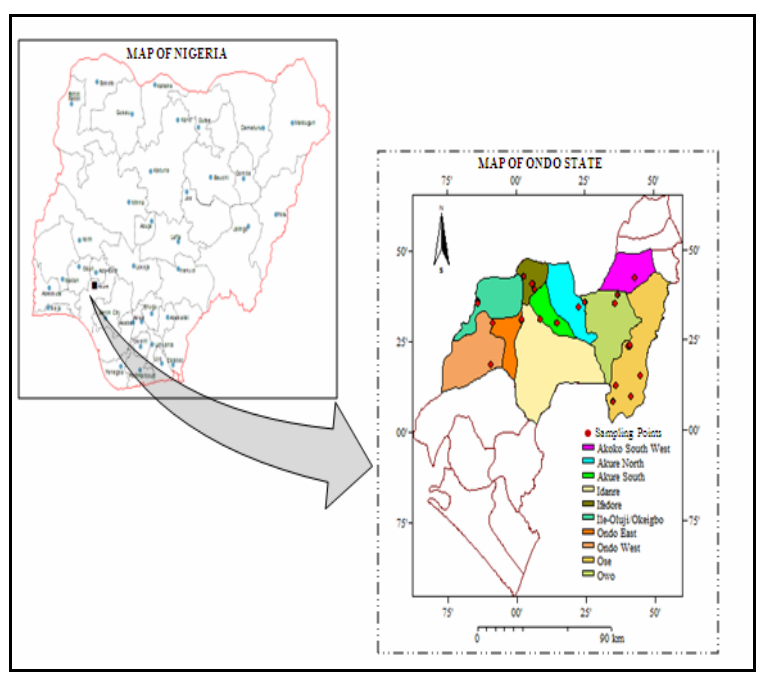

Fig 1.0: Sampling Locations
Rainfall was modeled as a constraining factor for cocoa yield in the state. The modeling was carried out using the Integrated Land and Water Information System (ILWIS 3.0) and ArcGIS 9.3 softwares-a Geographic Information System (GIS) used for geological analysis.

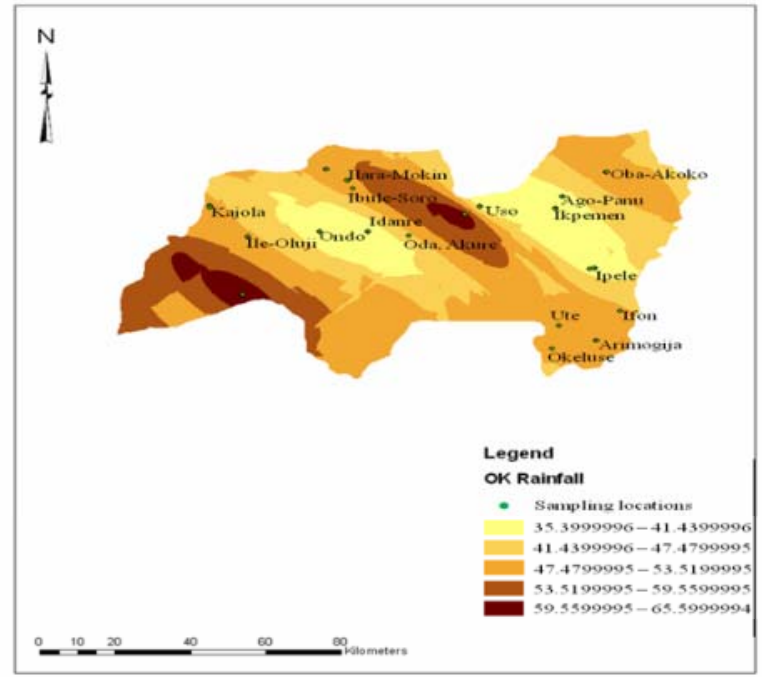

Fig 1.1: Rainfall distribution in the cocoa producing area

Figure 1.1 shows the rainfall distribution within the sampling areas, and has distinctively shown the rainfall range of each sampling point. A careful 
Am. J. Sci. Ind. Res., 2010, 1(2): 127-134

comparison of the rainfall distribution (Figure 1.1) with the yield tables (Table $1.3 \mathrm{a}-\mathrm{c}$ ) reveals that the high cocoa producing local governments such as Idanre, Ile-Oluji, Ondo \& Owo (see Tables 1.3 a - c) fall within rainfall range $3.5-5.35$. The plot of average yield and rainfall (Figure 1.2) illustrates this. From the plot, it can be inferred that cocoa yield is approximately the inverse of rainfall.

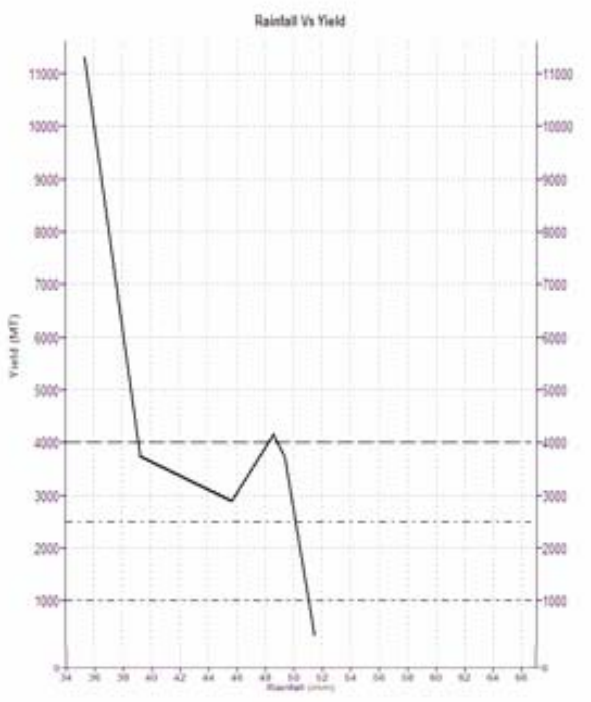

Fig (1.2) Rainfall VS Yield

Using the yield classification of cocoa production, yield greater than 4000 metric tons was taken as the 'Best yield', yield between 2500 \& 4000 metric tons taken to be 'Substantial yield', between $1000 \& 2500$ metric tons to be 'Moderate yield', and a yield below 1000 metric tons should be considered 'Poor yield'. That is, >4000MT-'Best', 2500 - 4000MT'Substantial', 1000 - 2500MT-'Moderate', \& $<1000$ MT_-Poor'. It is obvious from the Rainfall Vs Yield graph (Figure 1.2) that the rainfall range $35-$ 38.6 produce the Best yield, rainfall range $38.7-50.1$ produce Substantial yield, rainfall range $50.2-51.3$ produce a moderate cocoa yield, and rainfall above 51.3 produce a yield lesser than $1000 \mathrm{MT}$ which is considered to be Poor in this illustration. Table 1.5 shows the summary of this.

Table 1.5: Summary table Rainfall Vs Yield

\begin{tabular}{|c|c|c|}
\hline Yield Class (MT) & $\begin{array}{c}\text { Rainfall range } \\
(\mathbf{m m})\end{array}$ & Remark \\
\hline$>4000$ & $35.0-38.6$ & Best yield \\
\hline $2500-4000$ & $38.7-50.1$ & Substantial yield \\
\hline $1000-2500$ & $50.2-51.3$ & Moderate yield \\
\hline$<1000$ & $>51.3$ & Poor yield \\
\hline
\end{tabular}

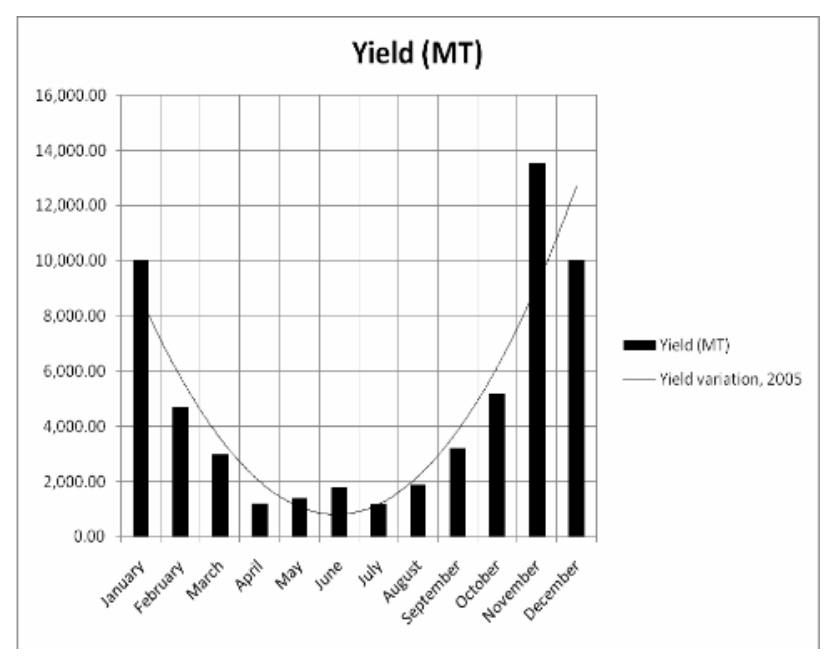

Fig 1.3: Monthly Yield variation, 2005

The 2005 monthly yield variation follows a rough parabolic distribution (see figure 1.3) with minimum around June / July. The best yield occurred from October to February. The rainfall pattern is opposite to cocoa yield with most of the rain occurring from March to July. Only April and August data produced a deviation from the hyperbolic form. The occurrence of too much rainfall reduces sunlight, reducing flowering and ripening of pods with a resultant effect in increase in (few produced) pod diseases (e.g. Black pod)

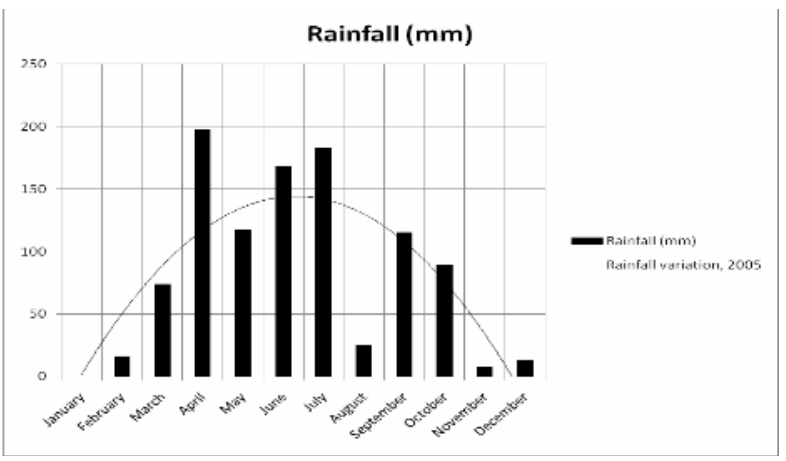

Fig 1.5: Monthly Yield variation, 2006

Based on the classification of yields into classes as in table 1.5 , it is evident that the best yield of cocoa (yield > 4000MT) was obtained around January February and October - December in 2005 (figure 1.3). However, the rainfall during this period was below $100 \mathrm{~mm}$. in the mid 2005 (June / July), the yield fell below $1000 \mathrm{MT}$ and rainfall in $150 \mathrm{~mm}$ vicinity 
(figures $1.3 \& 1.4$ ). This yield according to table 1.5 was tagged 'Poor'.

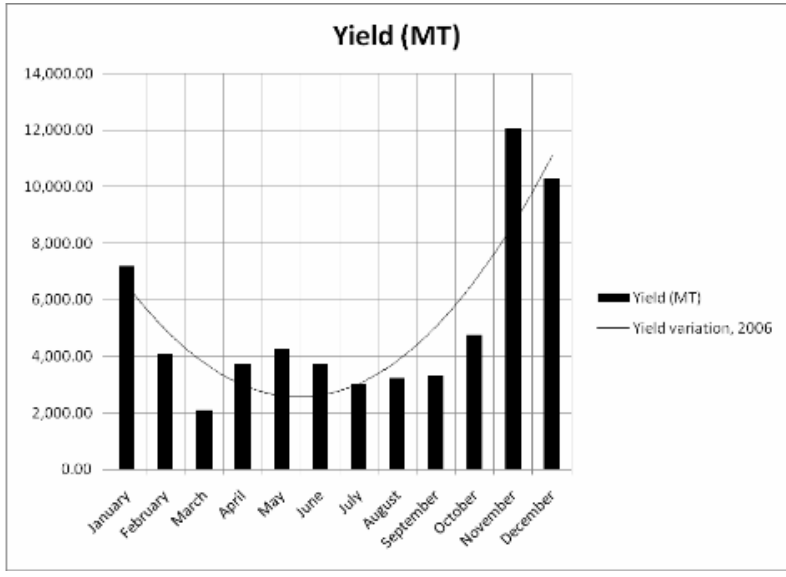

Fig 1.4: Monthly Rainfall variation, 2005

The monthly cocoa yield oppositely correlates with rainfall by comparing the yield and rainfall bar chats of figures $1.5 \& 1.6$.

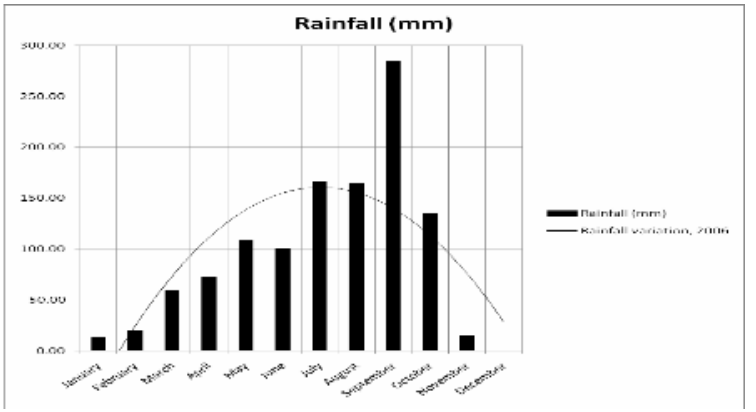

Figure 1.8: Monthly Rainfall variation, 2007

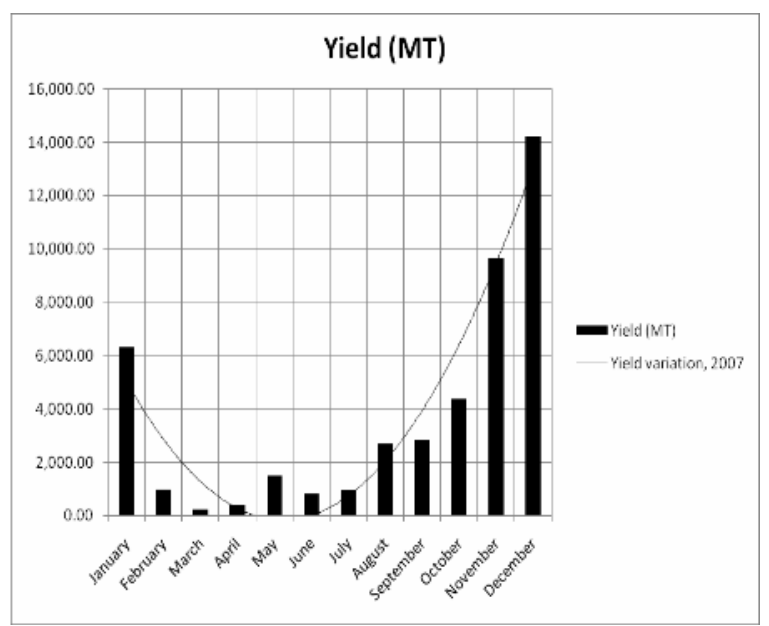

Fig 1.6: Monthly Rainfall variation, 2006
The yield variation denoted by the parabolic function (figure 1.7) became virtually zero around May / June of the year. It can be said, therefore, that cocoa yield around this period theoretically vanished in all the areas of study.

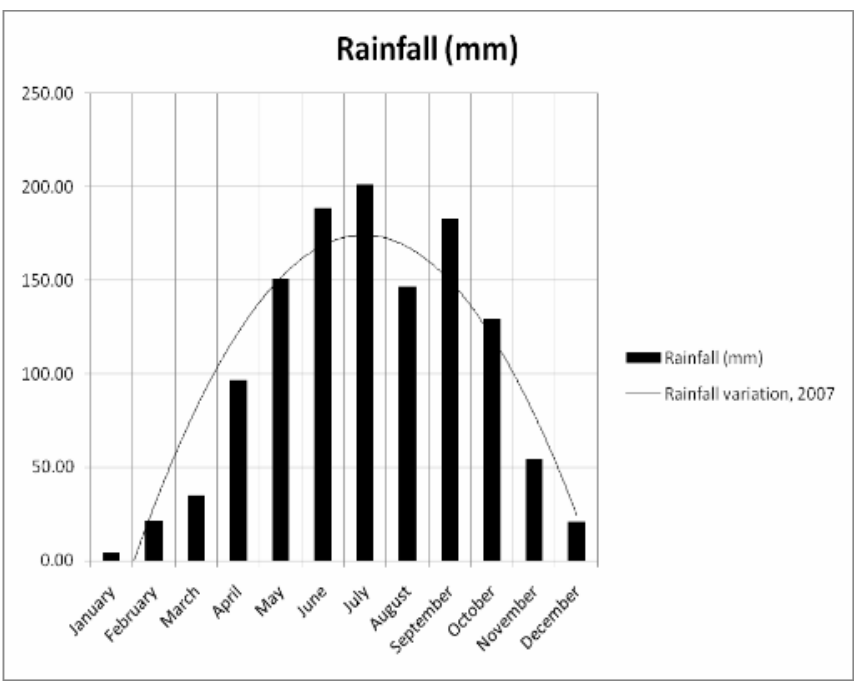

Fig 1.7: Monthly Yield variation, 2007

The monthly rainfall is successively high between April to October, 2007. If there is a low after a high monthly rainfall, the yield might have increased as there seems to be no dry period or adequate sunshine for cocoa pods to be free from fungal and other infection. This successive or continuous high monthly rainfall has adversely affected the 2007 cocoa yield (see figures $1.7 \& 1.8$ ).

\section{CONCLUSION}

This work shows that some areas within Ondo state cocoa producing areas could be rated as highly producing cocoa region. Such areas are Idanre and Ondo west; with yields far above 4000MT (Best yield). These areas were rated first and second, respectively, in cocoa production of $2005-2007$ yields ranking (see tables $1.3 \mathrm{a}-\mathrm{c}$ ).

However, the Federal Government, in its efforts to sustain and optimize cocoa production in the country, should encourage both local and foreign investors to invest heavily on cocoa production in the following areas: Idanre, Ondo west, Akure, Ore, lle-Oluji, Owo, Alade e.t.c, because the areas are within the highly 'placed' zones in the $2005-2007$ ranking of Ondo state. 
It was also observed that cocoa production has severely suffered towards the middle of the years due to continuous heavy downpour which characterize this period. However, cocoa thrives under little rainfall as experienced in October - February period of the year.

\section{ACKNOWLEDGEMENTS}

Appreciation goes to the National Space Research and Development Agency (NASRDA) of Nigeria for providing the financial backing to carry out this research work.

\section{REFERENCES}

Cacao Vs. Cocoa: Updating Your Chocolate Vocabulary". http://www.allchocolate.com/understanding/cacao-vscocoa/. Retrieved 2007-11-12.

Chocolate

Facts".

2005-06-11. http://www.calacademy.org/exhibits/chocolate/chocolat e.php. Retrieved 2007-11-12.

"Chocolate History Time Line". http://www.chocolatemonthclub.com/chocolatehistory.h tm. Retrieved 2007-11-08.

"Cocoa: From Bean to Bar," Urbanski, John, Food Product Design, May 2008

Adegeye, A.J (1996). Production and marketing of cocoa in Nigeria, problem and solution in Proceeding of National seminar on Revolutionizing Nigeria's cocoa Industry, Ibadan.

Ajobo, O (1980). Economic of cocoa production. In: Production of cocoa, coffee and tea in Nigeria. The Cocoa Board, Cocoa House, Ibadan, Nigeria. pp. 137140.

Aliyu Z.O. (2002), Site suitability analysis using Geospatial Information System, A case study of aero port for RECTAS, Ile-Ife, African Association of Remote Sensing of the Environment (AARSE).

Bayard V, Chamorro F, Motta J, Hollenberg NK (2007). "Does flavanol intake influence mortality from nitric oxide-dependent processes? Ischemic heart disease, stroke, diabetes mellitus, and cancer in Panama". Int $J$ Med Sci 4 (1): 53-8. PMID 17299579. PMC 1796954. http://www.medsci.org/v4p53.htm.

Buijsse B, Feskens EJ, Kok FJ, Kromhout D (February 2006). "Cocoa intake, blood pressure, and cardiovascular mortality: the Zutphen Elderly Study". Arch. Intern. Med. 166 (4): 411-7. doi:10.1001/.411. PMID $16505260 . \quad$ http://archinte.amaassn.org/cgi/content/short/166/4/411.

Burrough, P.A., 1986, Principles of Geographic Information Systems for Land Resources Assessment, Oxford: Clarendon Press.

Central Bank of Nigeria (CBN), (1998). Annual report and statement of accounts for the year 1998. Central Bank of Nigeria. pp. 7-9.

Egbe, N.E (1989). Soils and nutrition problems of cocoa, coffee, cashew and tea. In: Tree Crop Research, $2^{\text {nd }}$ Edn, Cocoa Research Inst., pp: 28 - 38.

Ekanade, O (1985a). The Impact of Cocoa Cultivation on Soil Properties in South Western Nigeria. Unpublished Ph.D Thesis, University of Ife.

Ekanade, O (1985b). The Effect of Cocoa Cultivation on Some Physical Properties of the Soil in Southwestern Nigeria. The International Tree Crops Journal 3, 113124.

Godchild, Michael F. (2009), "Geographic Information System." Microsoft Encarta.

Michael N. Demers (2004), Fundamentals of Geographic Information System ( $2^{\text {nd }}$ Edition), John Wiley \& Sons, Inc.

Nkang M.N., et al (2007), Investment in cocoa production in Nigeria: A cost and return analysis of three cocoa production management systems in the Cross River state cocoa belt, Journal of Central European Agriculture

Schroeter H, Heiss C, Balzer J, et al. (January 2006). "Epicatechin mediates beneficial effects of flavanol-rich cocoa on vascular function in humans". Proc. Natl. Acad. Sci. U.S.A. 103 (4): 1024-9. doi:10.1073/pnas.0510168103. PMID 16418281.

Taubert D, Roesen R, Schömig E (April 2007). "Effect of cocoa and tea intake on blood pressure: a metaanalysis". Arch. Intern. Med. 167 (7): 626-34. doi:10.1001/archinte.167.7.626. PMID 17420419.

U.S. Department of State Country Reports on Human Rights Practices, 2005 Human Rights Report on Côte d'Ivoire.

Udo, R.K. (1978), Geographical Regions of Nigeria, London, Heinemann, Nairobi, Ibadan, Lusaka, pp 26 27. 